This item was submitted to Loughborough's Research Repository by the author.

Items in Figshare are protected by copyright, with all rights reserved, unless otherwise indicated.

\title{
The role of agglomeration economies for SME transnationalisation: Bypassing the global urban service nexus?
}

PLEASE CITE THE PUBLISHED VERSION

https://doi.org/10.4324/9781315604435

\section{PUBLISHER}

(C) the Authors. Published by Routledge

\section{VERSION}

AM (Accepted Manuscript)

\section{PUBLISHER STATEMENT}

This work is made available according to the conditions of the Creative Commons Attribution-NonCommercialNoDerivatives 4.0 International (CC BY-NC-ND 4.0) licence. Full details of this licence are available at: https://creativecommons.org/licenses/by-nc-nd/4.0/

\section{LICENCE}

CC BY-NC-ND 4.0

\section{REPOSITORY RECORD}

Van Meeteren, Michiel. 2019. "The Role of Agglomeration Economies for SME Transnationalisation: Bypassing the Global Urban Service Nexus?”. figshare. https://hdl.handle.net/2134/36832. 
The role of agglomeration economies for SME transnationalization: Bypassing the global urban service nexus?

Michiel van Meeteren (michiel.vanmeeteren@ugent.be) ${ }^{1}$

Ghent University, Geography Department, Krijgslaan 281 S8, 9000 Ghent, Belgium

\title{
Published as: (please refer to the published version)
}

Van Meeteren, M. (2013). The role of agglomeration economies for SME transnationalization: bypassing the global urban service nexus? In C. Tamásy \& J. R. Diez (Eds.), Regional Resilience, Economy and Society (pp. 231-251). Farnham: Ashgate.

\begin{abstract}
A growing number of West European Small and Medium Sized Enterprises (SMEs) attempt to reap the benefits of low production costs and growing demand in emerging Asian economies, by way of firm transnationalization. Successful transnationalization entails adaptation to completely different institutional environments. This requires the acquisition of both foreign knowledge and social networks. The economic geography literature tends to stress the importance of agglomeration externalities in this regard, since it is in large agglomerations where transnational connections are common. This paper gauges the the role of agglomeration externalities for eleven Dutch transnational SMEs that built a subsidiary in East or Southeast Asia. Contrary to expectations, agglomeration externalities in the home environment played a limited role. The researched SMEs source knowledge abroad, on conferences and with their non-local suppliers. Advanced producer services played a very modest role in this regard: the global urban service nexus emphasized by world cities research is often circumvented. As such, the findings of this paper do not corroborate the idea that regional resilience in less urbanized areas ought to stem from embracing urbanization. Instead, analyzing resilience should employ a finer distinction of different kinds of agglomeration externalities and their respective geographical ranges and scales.
\end{abstract}

\section{Introduction}

A defining feature of the contemporary world economy is the 'deepening integration' of global production systems (Dicken 2007). Between 2000 and 2010 global Foreign Direct Investment (FDI) stocks have risen with 157\% (Unctad 2000, 2010) signaling an enormous growth and complexity of the transnational linkages that make up global production networks (Coe et al. 2004). Consequently, the ability of firms, and indirectly the regions they reside in, to create linkages between economic spaces, through for example FDI, has become a quintessential innovation for firms to 'plug' themselves in these global networks (Saxenian 2006, Bathelt et al. 2004). Accounts of regional economic growth under

\footnotetext{
${ }^{1}$ The author would like to thank David Bassens and two anomynous reviewers for comments on earlier versions of this paper and Ate Poorthuis for his cartographic input .
} 
conditions of globalization tend to emphasize the urban character of this stage of capitalism. A globalized knowledge-based economy is driven by a continuous flow of new innovations and it has become commonplace to stress the importance of agglomeration externalities in this respect (Krätke 2007). This poses important questions for the economic resilience of localities and firms outside urban cores (Malecki 1993, Simmie and Martin 2010). To what extent are they able to adapt and participate in a knowledge based economy if this is contingent on 'urban' features relatively absent within their locality (Birch and Cumbers 2010)?

Woods (2007) argues that many key texts in globalization research have a spatial bias towards the urban. The position of rural spaces is often defined by their absence from the narrative. However, several studies show that innovative enterprises in rural areas tend to follow different innovation strategies than their urban counterparts (Kalantaridis and Bika 2011, Huggins and Johnston 2009). This then begs the question to what extent 'urban' features are necessary for being competitive in the global economy. There is no absolute demarcation between 'urban' and 'rural' spaces and there are a lot of in-between periurban and suburban spaces that neither would qualify as ideal typically urban or rural (Errington 1994). Despite claims that the contemporary 'urban' is everywhere (Amin and Thrift 2002), the agglomeration externalities arguably central to innovation do tend to work on specific geographical scales, therefore it is likely that the location of firms within this urban-rural continuum does matter. Therefore, it is essential to elaborate on the scales and thresholds at which the various types of agglomeration externalities occur. Conversely, that will provide us with a notion of which kinds, and to what degree, enterprises located in rural areas we expect to be excluded from some types of these agglomeration externalities.

The empirical data for this study concerns non-affiliated Dutch Small and Medium sized Enterprises (SMEs) that have successfully set up a foreign subsidiary in the emerging economies of East and Southeast Asia. Transnationalizing SMEs are a relatively recent phenomenon. In the literature it has long since been assumed that only big companies had sufficient resources to hedge against uncertainties of an economic environment so vastly different than their home environment (Caves 2007). These are cases of transnational entrepreneurship (Yeung 2009); the companies have successfully implemented a sociological-organizational innovation that allows them to tap into geographically distant, and very different, environments abroad (van Meeteren 2011). Central to this study are the sources of knowledge, and their geographical pattern, in the external environment of the firm that 'taught' a company how to successfully transnationalize itself. One would expect that, since this innovation concerns cultural knowledge on different business environments and favorable positionality (Sheppard 2002) in transnational networks, an urban environment would play an important role in their transnationalization. However, this was found to be much more nuanced. 
To elaborate this nuance, the remainder of the paper is built up as follows. Section two reviews the agglomeration externalities literature that explains the role of urban environments in globalization. Section three examines the utility of agglomeration externalities for the sample of transnational SMEs studied. Section four discusses what the research findings could imply for our understanding of the economic resilience of less urbanized regions and provides avenues for thinking about different circuits of how companies can reap the benefits of globalizing production systems.

\section{The urban frame of globalization research}

The relation between innovation and agglomeration externalities is most forcefully stressed by Edward Glaeser's (2011) work on the 'triumph of the city' which argues that cities - due to their size and circulation of ideas - provide the most important source of innovation in the contemporary era. However, the long tradition of work on agglomeration externalities provides the necessary fine distinctions and specifications on the mechanisms involved. Following Neffke's (2009: 22-27) literature overview of the matter, four distinct types of agglomeration externalities can be identified.

Urbanization externalities are the external economies of scale derived from the size of an urban area such as the size of the local market and the combined local carrying capacity for large scale amenities such as intercontinental airports and seaports, and more recently: sufficient Internet bandwidth. It is important to note that this type of externalities does not presuppose any qualitative definition of what an 'urban' area is. Instead these externalities arise out of a quantitative dimension: the sheer mass of producers and consumers located within a particular geographical threshold.

Porter externalities (Porter 1998) concern innovations that are spurred by competition between firms. Porter argues that local competitors in fierce competition for their home market incentivizes companies to be on the cutting edge in terms of price, product innovations and service. However, whether this is a localized phenomenon in a globalized age depends on the structure of the industry and the geography of their respective home market, which is not necessary local, and is therefore an open empirical question.

Jacobs Externalities (Jacobs 1969) refer to the benefits that firms can reap from being colocated in a local heterogeneous urban environment. Local economic diversity is taken to support the cross fertilization of ideas that ultimately result in the new combinations that exemplify innovations. In the case of transnational entrepreneurship and its necessity to acquire foreign cultural knowledge and networks, it seems important that the presence of diaspora can play an important role. For example, Brienen et al. (2010) find a positive effect of diaspora in explaining the metropolitan location of inward Chinese and Indian FDI in the Netherlands. If this plays also plays a role in the opposite movement, outward FDI, we would expect that transnationalizing SMEs that are located in the Dutch metropolitan core are more likely to transnationalize with these regions. 
Localization externalities refer to the external benefits that firm's accrue by being colocated with firms that are engaged in similar activity. Either as competitors, collaborators, or up and down in the supply chain. These refer to the localized knowledge spillovers, facilitated by face-to-face contacts and labor mobility, from which clusters or industrial districts derive their regional competitive advantage through local buzz (Storper 1997, Storper and Venables 2004). Two important critiques have to be taken into account here. The first critique emphases that these spillovers are not necessarily an urban phenomenon. Asheim et al (2007) stress that this is probably only strongly the case for volatile symbolic knowledge. Moreover, they (Asheim et al.: 667) state that "the importance of such buzz is diminishing as a consequence of the reduced importance of tacit knowledge in industrial districts and cluster because of outsourcing, offshoring, and foreign direct investments. This critique is supplemented by another strand of research (Amin and Cohendet 2004, Boschma 2005) which emphasizes that geographical proximity is not the necessary conduit for tacit knowledge transfer. Organizations, facilitated by technological advances in communications and increased mobility, find ways to learn from each other through remote linkages. This further complicates the already fuzzy geographical assumptions (Taylor 2010) regarding the spatialization of economic clusters. All these observations cast enough doubt over an a-priori assumption that localization externalities are neccesary for SMEs to learn how to transnationalize.

\section{The world city thesis.}

A specific kind of localization economy that has received significant attention are concentrations of service industries in a specific number of sites in the world economy: the global/world cities. The world city thesis provides a another window through which we can understand the urban frame of transnationalization processes. Instead of studying the properties of cities as a spatially bounded entity, world city research emphasizes the role of the interconnections between cities and associated flows of knowledges and people as being transformative of the contemporary world economy (Taylor 2004). Central in the empirical analyses of world cities are the global networks of Advanced Producer Services (APS) firms. These sectors are illustrative of a more general observation that services play an important role in externalizing knowledge inputs in flexible modes of production (Bryson et al. 2004). Expatriate networks (Beaverstock and Boardwell 2000) and business travel (Faulconbridge et al. 2009) facilitate in the creation and diffusion of that knowledge. Since APS firms serve as knowledge inputs to transnational corporations their geography is at least somewhat related to the organization of transnational corporations (Parnreiter 2010). Therefore, if we want to understand how SMEs 'learn' how to transnationalize, studying their interdependencies with service firms is a logical passing point.

\section{Transnational entrepreneurs and their urban needs}

Now that we have established an overview of the various kinds of agglomeration externalities that could benefit an SME in the transnationalization process, this section 
assesses the relevance of these externalities from a detailed study of the transnationalization process of eleven Dutch SMEs. The empirical data is derived from a broader study examining the knowledge dynamics of SME transnationalization (van Meeteren 2011). This study did not stratify its case selection to urban/rural variables. Instead, throughout the Netherlands, cases were identified. Since there exists no usable sampling frame on transnational SMEs in the Netherlands the companies were selected through various snowball sampling methods. The Dutch Federation of Exporters (FENEDEX), the Dutch Development bank (FMO), publications of the Dutch ministry of economic affairs and various experts provided contact information of possible respondents. This was supplemented with a countrywide newspaper and specialized press search to correct for possible biases in the case selection process. In the end, eleven eligible companies were identified which were subsequently interviewed in the period between June 2010 and April 2011. The interviews consisted of longitudinal probing of the transnationalization history through the critical incident technique (Chell 2004, Stam 2007), the creation of a participant-aided sociogram of the firm's external information networks (Hogan et al. 2007) complemented with the qualitative executive interviews (Schoenberger 1991) to gather further information on the companies' strategy, finance and sector characteristics. The resulting overview of the firm's knowledge and procurement networks and its social context allows us to investigate the relevance of the different types of agglomeration externalities utilized for transnationalization.

\section{[Insert table 1 here - portrait]}

Table one shows some descriptive characteristics of the surveyed companies. All companies, except \#11 are active in global niche markets, usually catering a specialized service or product to a well-defined market- often global lead firms, congruent with Fujita's (1995) finding that these are the most likely sectors in which SMEs are able to transnationalize. Therefore, for these ten respondents the size of the local market, an important feature of urbanization economies was not relevant. Moreover, all firms except \#2, \#8, \#7 and \#11 show characteristics of a Dutch variety of the traditional 'mittelstand' firm (Gertler 1996, Grotz and Braun 1997): highly specialized, privately owned, hi-end capital goods input suppliers related to the manufacturing sector which were traditionally embedded in localized production networks but which have seen strong globalization in recent years (Berghoff 2006).

\section{[insert Figure 1 here - portrait]}

\section{Figure 1 Location of respondents and the Randstad area}

Figure one shows the spatial distribution of the surveyed firms. As we can see, all but three firms are located outside the Randstad area and none are located in the Amsterdam metropolitan area. Instead the non-Randstad companies tend to be located in peri-urban areas and secondary urban centres of the Netherlands, with the exception of firm \#10 
which is strongly embedded in the Southeast Netherlands technological cluster (cf. Lagendijk \& Boekema 2008). In itself, the location of the enterprises corresponds to the historical patterns of industrial geography in The Netherlands. The home regions of the companies were main beneficiaries of industrial suburbanization in the mid 20th century and have had relatively little deindustrialization (de Smidt and Wever 1990). Moreover, they fit the location profile of companies that engage in materials processing (de Smidt 1989) and have a traditional high export propensity (Atzema 1994). All companies had an historical embeddedness within their respective region. The current management either bought themselves in or the firms spun out of other firms in the region. All firms were firmly tied to their environment due to the spatial fixity of their human capital stock as can be expected for mature firms (Stam 2007), and none were planning relocation. As such the location and genesis of these companies confirms to the expectations of traditional Dutch firm demography (Pellenbarg and van Steen 2003); what makes them exceptional is their transnationalization while being relatively outside the urban core of the Netherlands.

\section{Necessary amenities for transnationalization}

The SMEs relied heavily on the availability of good airline, Internet and, if applicable, seaport facilities that sustain themselves through urbanization externalities. Since SMEs tend to have relatively modest financial means the lower costs associated with external economies of scale were often indispensable. However, geographical scale effects do apply. On average, the principal employee or executive that coordinated interaction between the home location and the Asian subsidiary travelled to Asia every two months, and other employees generally had lower flight intensities. In the Netherlands, airport facilities are highly developed and it was reported that the maximum three hours travel to an airport was no more than a possible inconvenience with such a travel frequency (cf. Pellenbarg and van Steen 2003). Having sufficient Internet bandwidth was considered equally important. In all the companies, Voice-over-IP applications, such as Skype and server infrastructure were key technologies enabling the smooth interaction of the SMEs with their foreign subsidiaries. Here also, the current location supplied sufficient Internet access and put them on the right side of the digital divide. In short, some amenities that exist due to the economics of scale accrued to urban areas were indispensable for transnational SMEs but the hinterland of these amenities was in the case of the Netherlands not restricted to the core urban areas, allowing SMEs in researched periurban and secondary urban sites to sufficiently profit as well.

\section{Knowledge linkages}

The principal aim of the study is to trace the history of the transnationalization process of the SME and to identify crucial actors in the firm's environment, and their geographies, that enabled the firm to successfully engage in the transnationalization process. The linkages are categorized by the distinction between 'vertical' and 'horizontal' linkages (Malmberg and Maskell 2006). Vertically linked firms specialize in different stages of the production process, in which one firm's input is the other's output. They possess "knowledge, 
experience or skills useful for undertaking dissimilar but complementary activities" (idem: 5). Learning occurs as a byproduct of the traded interdependencies (Storper 1997) upstream and downstream in the firm's commodity chain. Horizontal linkages refer to knowledge shared between firms who do not interact within the same commodity chain and are usually competitors or active in different niches. In addition, special attention was paid to 'service' linkages to gauge the relevance of producer services firms.

Table two provides an overview of the various types of vertical and producer service linkages found that provided crucial knowledge in the transnationalization process. The different linkages observed during the research were categorized in different types according to relevant observed features and a box in the table is checked if a particular type of linkage was found in a case. Each of the firms reported both relevant upstream or downstream and service linkages. Although the kinds of linkages differed from firm to firm. The different types are further elaborated below.

\section{[Insert table 2 here - landscape]}

\section{Client (downstream) types}

1. Client demand. From a macro perspective this would be called 'market demand'. However, from the viewpoint of the individual firm it often has a social connotation. Clients and suppliers know each other and switching suppliers is something firms hesitate doing. Several firms reported that their clients started to demand lower prices, threatening to otherwise buy from the competition who did already did produce or procure in 'Asia'. For the firms reporting this type of linkage, that was an important push factor for transnationalization.

2. Follow the customer bridgehead. A more sophisticated variety of the client demand is when a previously transnationalized customer, usually a big original equipment manufacturer (OEM), 'invites' its supplier to transnationalize. The OEM wants to be able to source locally but would prefer to do so with an established supplier (Johanson and Mattson 1988). Hence, the transnationalized SME gets a starting portfolio of customers abroad. With this type, it was recorded that the OEM would sometimes even provide practical assistance in the transnationalization process.

3. Agent/Distributor bridgehead. In the 'classical' literature on firm transnationalization (Johanson and Vahlne 1977) agents and distributors abroad were considered the key knowledge brokers in a transnationalization process. They are still an indispensable source of knowledge to th firms reporting this type of linkage. 
4. Host country clients. The last category of knowledge sources on the client side is when the firm has established a foothold in the Asian market either through exports previous to subsidiary establishment or after the first steps have been initiated. Having to directly negotiate with foreign customers was found to be an important source of cultural and institutional knowledge.

When reviewing the interdependencies from the client side it is striking how little the local scale, and therefore 'localization economies' matter as learning environments on the 'home' side of the SME. In general, only the first linkage type was to a certain extent national, Dutch clients being the principal cause, but these are rather to be considered Porter externalities than localization externalities and not confined to an urban scale. Instead, clients in the host country were reported to be important sources of knowledge. Contacts with agents and distributors usually emerged from conference and trade fair visits supporting the argument that these temporary 'clusters' play an important role in facilitating the forging of, eventually, trustworthy business ties with new environments (Maskell et al. 2006). Another important notion is the role of established clients whom that transnationalized themselves and 'take on board' some of their trusted suppliers in the transnationalization process. Thus links established in the home country, can transnationalize together in the reconfiguration of production systems, this means that the relation stays but the home country environment loses its significance as knowledge conduit.

\section{Suppliers (upstream) types}

5. OEM supplier/client. In two recorded cases, OEM firms played an important role as a space, rather than a source of knowledge. In these cases, these large companies organized their own conference-like gatherings to bring together their suppliers or intermediate clients in order to promote new products and facilitate interaction.

\section{Local suppliers. All respondents who produce in Asia eventually started to source} materials locally. In most instances, this went further than a market relationship and a reciprocal learning relationship emerged. The Dutch firm would usually teach their supplier to deliver goods according to their quality requirements and in return, the supplier became an important source of knowledge and business contacts.

A salient finding is that companies in general did not learn from their suppliers on the 'home' side of the transnational space, even if these suppliers did procure in Asia themselves. Fear of 'cutting out the middleman' by the supplier is the logical explanation for this missing type of knowledge sharing. None of the firms studied had a strong localized client or supplier base in the Netherlands. Instead most of them served international markets and international supply chains, hence geographical proximity did not play a role in the vertical interactions on the 'home side'. On the 'host side', geographical proximity played a much more articulated role. Each of the respondents had at some point 
to decide where to locate their foreign subsidiary and 'classical location factors' involving the physical flow of goods and labor market externalities were usually decisive in this regard. As a consequence, some of the surveyed SMEs in the same industry only got to know each other after they found themselves being co-located on the same industrial park in Asia! They had independently concluded that this location was optimal for their industry. These decisions were to a significant extent influenced by knowledge gathered through contacts in the host country. Consequently, localized learning mostly took place on the 'host' pole of the transnational pipeline.

\section{Service linkages}

APS firms are considered to play an important role in the flexibilization of production systems, allowing for an external division of labor (Bryson et al. 2004) for non-routine tasks of the firm. APS firms tend to offer a wide variety of services related to transnationalization such as legal and accounting advice, business strategy consulting and partner matchmaking. In the researched sample, two strongly divergent opinions on the efficacy of these APS for SMEs emerged. Although some embraced their functions, others found them expensive relative to what they had to offer. Moreover, almost two thirds of the respondents considered their services on the non-juridical side of business -such as human resources and strategy- woefully inadequate, and preferred using local services instead. APS services were regarded as being too much geared towards Western corporate business practices and therefore unable to teach them how to do business with locals. It should be noted that the more 'advanced' services offered by APS can be irrelevant for SMEs. SMEs generally do not need access to haute finance capital markets and neither are publicly listed. Not facing these governance challenges, arguably it is easier for SMEs to bypass APS firms. Three different sourcing strategies for services were identified.

7. Use of local producer services. Many respondents advocated the use of local independent accountants, lawyers and local consultants. Not only because these were cheaper but also because they had a better understanding of local standards and customs and preferred access to local governments. Often, reliable local service providers were solicited through agents/distributors, expat networks, or specialized Netherlands-Asia consultants.

8. Reluctant use of APS. Some SMEs did use the services of APS but only if absolutely necessary, usually in safeguarding legal and tax issues.

9. Embracing APS. Four SMEs regarded the APS firms as good partners. In general these were the SMEs where the entrepreneur had a 'corporate' background because of previous work experience.

These divergent, and generally strong opinions about the utility of producer services usually coincided with a similar appraisal of the business ecology of the expat world. Expat communities consist of a closely knit transnational elite working for big multinational 
companies, the diplomatic community and NGOs and tend to create their own social spaces (Beaverstock 2002), for example in 'national societies'. For some, it provided a social arena when dealing with Western companies operating in the same locality and could provide knowledge about local service providers and facilities of the Dutch foreign ministry (cf. Li and Scullion 2006). For others it was not a social environment they really felt comfortable in. They felt considerable social distance between the corporate expat lifestyle and their own. Moreover, even when they did enjoy the social occasions of the expatriate life world, entrepreneurs noted that the expat life did not yield particular useful knowledge how to deal with local Asian suppliers or business practices. This disposition is captured in the following interview excerpt:

\footnotetext{
"At gatherings of the Dutch expatriate world I have met a lot of people who work for Philips or Ernest and Young. They experience China very differently than we do. They come to a job and they are the 15th person who has had that job: Computer, house and office are there. The house is beautiful and it is the same house as all the others are in; it is a polished life. Because we are poor we had to delve into Chinese society and visit our suppliers in a shabby old van; being at Chinese lunches where drunken people fall of their chairs." - Firm 4.
}

This adheres to Beaverstock and Boardwell's (2000) observation that the expat world tends to be a relatively isolated transplantation of 'Western' corporate business practices. Similarly, people with an Asian background featured prominently as knowledge sources in the transnationalization process but they were seldom recruited from the established Asian expatriate communities in the Netherlands. Instead, either Asian exchange students or trusted contacts in Asia were utilized. Thus the relationship between expatriates and inward FDI (Brienen et al. 2010) does not automatically apply to outward FDI as well, and this also shows that the obvious Jacobs externalities in this case -transnational cultural contacts- can be appropriated through non-local linkages. In general, if agglomeration economies played a significant role in the process it was in the host rather than the home society in which a shared cultural framework provides entrances into a new business world. However, this is less contingent on the APS complex than would be expected from the world city literature.

\section{[Insert table 3 here - portrait]}

\section{Horizontal linkages}

Table three, shows a similar overview of the horizontal knowledge linkages reported by the respondents. Horizontal linkages refer to knowledge shared between firms who do not interact within the same commodity chain and are usually competitors or active in different niches. In this case, the term refers to learning from 'peer' firms that are also transnationalized but are unconnected through supply chain linkages. Except for firm \#7, all firms reported such linkages. Learning between competitors can either emerge out of collaboration or through mimicry effects, which are supposedly stronger when firms are colocated (Maskell 2001). Only firm \#10 reported such localized home effects. However, 10 
out of 11 firms surveyed are active in niche markets and hence fully aware of who their global competitors are and follow them meticulously. They operate in 'small worlds'. Thus, in the sort of specialized niche industries these transnational SMEs operate, Porter externalities occur, but on non local scales. The sharing of knowledge was reported to primarily take place on conferences and in the expat circles, and in the context of associations. The three types of horizontal linkages identified are explicated below and summarized in table 3.

\section{Mimicry effects, When your competitor 'goes' to Asia, investigating a possible} transnationalization yourself tends to become a strategic priority. This finding was confirmed by two cases where the main competitor of the focal firm was reported to have transnationalized after the focal firm's decision to do so, allegedly 'inspired' by them.

2. Knowledge sharing between competitors. Being in a small world does not imply that rivalry between firms automatically entails antagonism. Instead, sharing transnationalization experiences was often a focal topic since it did not involve discussing your proprietary technological know-how, but still provided a shared cognitive frame (Neffke 2009).

3. Knowledge sharing between 'peers'. Similar to type 2, except that this concerned knowledge sharing between a transnationalized peer who was not a direct competitor, because they were in a (slightly) different industry. Yet, the shared transnationalization experience provided sufficient cognitive overlap to enable meaningful learning.

As with the vertical linkages, we see that a lot of the processes that are ascribed to 'localization' economies are not bound to the local scale, but instead can fully operate within the transnational social networks the SMEs are embedded in. The scale is not-local, let alone 'urban' in the home country.

\section{Discussion and conclusions: Alternative models of TNC formation}

Because this study only examines a very specific innovation -transnationalization- within a relatively small sample of firms, it was never intended to generalize its findings to industrial structures or regional economies. However, it does lend credibility to a view that macro studies that examine innovative activity in regions and studies that look the actions of the individual firm can lead to radically different conceptions of the role of space in the transnationalization process. Despite having very limited external interdependencies with their immediate environment, the firms studied here were not footloose. They regarded their workforce and their specific competences -human capital- crucial in creation and sustaining their competitive advantage as a firm. Human capital is constrained in space due to personal biographies and demography. Although the firms studied did not report that constraint, having sufficient -in particular technical- skills available in the regional labor 
market would be a more important 'urban' feature of transnationalization processes than cultural knowledge spillovers. As far as transnationalization is concerned, this study points to the importance of tapping into global infrastructure networks as an urban amenity but gives little support to the notion that other types of agglomeration externalities play an important role on the specific urban scale beyond the exceptional case of a localized production cluster. The functional effects of 'localization', Jacobs and Porter externalities play their parts, but on a transnational scale, through transnationalized social networks.

The findings do teach an important lesson about the resilience of less urbanized regions that are seeking to 'catch up' in a 'knowledge based economy'. Innovation grows from the relations that are already present in the firms' environment and innovative entrepreneurial firms find ways to 'break out' of any local constraints, a phenomenon already described by Taylor and Wood in 1973. As such this study adds more evidence to others (Kalantaridis and Bika 2011, Huggins and Johnston 2009) which have noted that non-urban firms primarily rely on translocal rather than local networks. In this study this often implied that the firms were able to bypass the 'corporate' circuits of transnationalization and associated cultures to directly do business with counterparts in Asia. In other words: there exist different circuits of transnationalization and possibly SMEs are able to derive competitive advantage by bypassing the 'corporate' logic of transnationalization that is chronicled in for example the world cities literature. Policy makers in less-urbanized regions therefore ought to be sharp on which sort of 'urban' functions they lack for the specific industrial endowment of their region instead of promoting some general 'urbanization' strategy. Paraphrasing Freeman \& Soete (1997, p. 353) 'catching up is not just a matter of running harder but it is also about finding new ways of doing things: run in a different direction'.

\section{References:}

Amin, A. and Cohendet, P. 2004. Architectures of Knowledge. Firms, Capabilities and Communities. Oxford: Oxford University Press.

Amin, A. and Thrift, N. 2002. Cities, Reimagining the Urban. Cambridge: Polity Press.

Asheim, B., Coenen, C. and Vang, J. 2007. Face-to-face, buzz, and knowledge bases: sociospatial implications for learning, innovation, and innovation policy. Environment and Planning C: Government and Policy, 25 (5), 655-670.

Atzema, O.L.A.C. 1994. Cirkelgang van het regionaal beleid, in Economisch Geografische Variaties, edited by O.A.L.C. Atzema E. and Wever. Assen: Van Gorcum, 76-99.

Bathelt, H., Malmberg, A., and Maskell, P. 2004. Clusters and knowledge: local buzz, global pipelines and the process of knowledge creation. Progress in Human Geography, 28(1), 31-56. 
Beaverstock, J.V. and Boardwell, J.T. 2000. Negotiating globalization, transnational corporations and global city financial centres in transient migration studies. Applied Geography, 20, 277-304.

Beaverstock, J.V. 2002. Transnational elites in global cities: British expatriates in Singapore's financial district. Geoforum, 33(4), 525-538.

Berghoff, H. 2006. The end of family business? The mittelstand and German capitalism in transition, 1949-2000. Business History Review, 80(2), 263-295.

Birch, K. and Cumbers, A. 2010. Knowledge, space, and economic governance: the implications of knowledge-based commodity chains for less-favoured regions. Environment and planning A, 42(11), 2581-2601.

Boschma, R.A. 2005. Proximity and innovation: A critical assessment. Regional Studies, 39(1), 61-74.

Brienen, M., Burger, M.J. and Oort, F.G. van. 2010. The geography of Chinese and Indian greenfield investments in Europe. Eurasian Geography and Economics, 51(2), 254-273.

Bryson, J.R., Daniels, P.W. and Warf, B. 2004 Service Worlds. People, Organisations, Technologies. London: Routledge.

Caves, R.E. 2007. Multinational Enterprises and Economic Analysis. Cambridge: Cambridge University Press.

Chell, E. 2004. Critical incident technique, in Essential Guide to Qualitative Methods in Organizational Research, edited by C. Cassell and G. Symon. London/Thousand Oaks/New Delhi: Sage, 45-61.

Coe, N.M., et al. 2004. 'Globalizing' regional development: a global production networks perspective. Transactions of the Institute of British Geographers, NS29, 468- 484.

Dicken, P. 2007. Global Shift, 5th edition. London/Thousand Oaks/New Delhi: Sage.

Errington, A. 1994. The peri-urban fringe: Europe's forgotten rural areas. Journal of Rural Studies, 10(4), 367-375.

Faulconbridge, J.R. et al. 2009. Corporate ecologies of business travel in professional service firms: Working towards a research agenda. European Urban and Regional Studies, 16(3), 195-308. 
Freeman, C. and Soete, L. 1997. The Economics of Industrial Innovation, 3rd edition. London: Routledge.

Fujita, M. 1995. Small and medium sized transnational corporations: Salient features. Small Business Economics, 7, 251-271.

Gertler, M. 1996. Worlds apart: The changing market geography of the german machinery industry. Small Business Economics, 8(2), 87-106.

Gleaser, E. 2011. Triumph of the City. New York: Penguin Press.

Grotz, R. and Braun, B. 1997. Territorial or Trans-territorial Networking: Spatial Aspects of Technology-oriented Cooperation within the German Mechanical Engineering Industry. Regional Studies, 31(6), 545-557.

Hogan, B.; Carrasco, J.A.; and Wellman, B. 2007. Visualizing personal networks: Working with participant-aided sociograms. Field Methods, 19(2), 116-142.

Huggins, R. and Johnston, A. 2009. Knowledge networks in an uncompetitive region: SME innovation and growth. Growth and Change, 40(2), 227-259.

Jacobs, J. 1969. The Economy of Cities. New York: Random House.

Johanson, J. and Mattsson, L.G. 1988. Internationalization in industrial systems-a network approach, in Strategies in Global Competition, edited by N. Hood and J-E Vahlne. London: Croom Helm, 287-314.

Johanson, J. and Vahlne, J-E. 1977. The Internationalization process of the firm. A model of knowledge development and increasing foreign market commitments. Journal of International Business Studies, 8(1), 23-32.

Kalantaridis, C. and Bika, Z. 2011. Entrepreneurial origin and the configuration of innovation in rural areas: the case of Cumbria, North West England. Environment and planning $A$, 43(4), 866-884.

Krätke, S. 2007. The metropolitanization of the European urban system in the era of globalization. In Cities in Globalization. Edited by P.J. Taylor et al. London: Routledge, 157-185.

Lagendijk, A. and Boekema, F. 2008. Global circulation and territorial development: SouthEast Brabant from a relational perspective. European Planning Studies, 16(7), 925-939. 
Li, S. and Scullion, H. 2006. Bridging the distance: Managing cross-border knowledge holders. Asia Pacific Journal of Management, 23, 71-92.

Neffke, F. 2009. Productive Places, the Influence of Technological Change and Relatedness on Agglomeration Externalities. PhD thesis, University of Utrecht: Faculty of Geosciences.

Malecki, E.J. 1993. Entrepreneurship in regional and local development. International Regional Science Review, 16(1-2), 119-153.

Malmberg, A. and Maskell, P. 2006. Localized learning revisited. Growth and Change, 37(1), 1-18.

Maskell, P. 2001. Towards a knowledge-based theory of the geographical cluster. Industrial and Corporate Change, 10(4), 921-943.

Maskell, P., Bathelt, H. and Malmberg, A. 2006. Building global knowledge pipelines: The role of temporary clusters. European Planning Studies, 14(8), 997-1013.

Meeteren, M. van. 2011. Learning by Bumping: SME Transnationalization as an sociological-organizational innovation process. MA thesis, University of Amsterdam: Faculty of Social and Behavioral Sciences.

Parnreiter, C. 2010. Global cities in global commodity chains: exploring the role of Mexico City in the geography of global economic governance. Global Networks, 10(1), 35-53.

Pellenbarg, P.H., and Steen, P.J.M. van. 2003. Spatial perspectives on firm dynamics in the Netherlands. Tijdschrift voor Economische en Sociale Geografie, 94(5), 620-630.

Porter, M. 1998. On Competition. Boston, MA:Harvard Business School Press.

Saxenian, A. 2006. The new argonauts, regional advantage in a global economy. Cambridge: Harvard university press.

Schoenberger, E. 1991. The corporate interview as a research method in economic geography. The Professional Geographer, 43(2), 180-189.

Sheppard, E. 2002. The spaces and times of globalization: Place, scale, networks, and positionality. Economic Geography, 78(3), 307-330.

Simmie, J. and Martin, R. 2010. The economic resilience of regions: towards an evolutionary approach. Cambridge Journal of Regions, Economy and Society, 3, 27-43. 
Smidt, M. de. 1989. A new profile of urbanization. Tijdschrift voor Economische en Sociale Geografie, 80(2), 69-74.

Smidt, M de. and Wever, E. 1990. An industrial geography of the Netherlands. London/New York: Routledge.

Stam, E. 2007. Why butterflies don't leave: Locational behavior of entrepreneurial firms. Economic Geography, 83(1), 27-50.

Storper, M. 1997. The Regional World. New York: The Guilford Press.

Storper, M. and Venables, A.J. 2004. Buzz: Face-to-face contact and the urban economy. Journal of Economic Geography, 4(4), 351-370.

Taylor, M. and Wood, P. 1973. Industrial linkage and local agglomeration in the West Midlands metal industries. Transactions of the Institute of British Geographers, 59, 127154.

Taylor, M. 2010. Clusters: a mesmerising mantra. Tijdschrift voor Economische en Sociale Geografie ,101(3), 276-286.

Taylor, P.J. 2004. World city network, a global urban analysis. London: Routledge.

UNCTAD. 2000. World Investment Report 2000, Cross border merges and acquisitions and development. New York: United Nations publications.

UNCTAD. 2010. World Investment Report 2010, Investing in a Low Carbon Economy. New York: United Nations publications.

Woods, M. 2007, Engaging the global countryside: globalization, hybridity and the reconstitution of rural place. Progress in human geography, 31(4), 485-507.

Yeung, H.W.C. 2009. Transnationalizing entrepreneurship: a critical agenda for economic geography. Progress in Human Geography, 33(3), 210-235. 
Table 1 Descriptive features of respondents

\begin{tabular}{|l|l|l|l|l|l}
\hline $\begin{array}{l}\text { Firm } \\
\text { no. }\end{array}$ & Industry & $\begin{array}{l}\text { Total } \\
\text { workforce }\end{array}$ & $\begin{array}{l}\text { Asian } \\
\text { subsidiary }\end{array}$ & $\begin{array}{l}\text { Other foreign } \\
\text { subsidiaries }\end{array}$ & $\begin{array}{l}\text { Year of first Asian } \\
\text { subsidiary }\end{array}$ \\
\hline 1 & Wood & $11-50$ & China (PRC) & - & 2000 \\
2 & Financial Services & $11-50$ & Vietnam & - & 2010 \\
3 & Machinery & $51-200$ & China (PRC) & - & 2008 \\
4 & Plastics & $51-200$ & China (PRC) & France, USA & 2007 \\
5 & Machine components & $51-200$ & China (PRC) & - & 2003 \\
6 & Outsourcing services & $1-10$ & China (PRC) & - & 2006 \\
7 & Outsourcing services & $11-50$ & China (PRC) & - & 2006 \\
8 & Agriculture & $201-250$ & Vietnam & India & 1997 \\
9 & Plastics & $11-50$ & China (PRC) & - & 2005 \\
10 & Machine components & $201-250$ & Malaysia & Turkey & 2009 \\
11 & Furniture & $51-200$ & Malaysia, & Australia, & 1998 \\
& & China (PRC) & USA & \\
\hline
\end{tabular}


Figure 1. Location of Respondents and the Randstad area

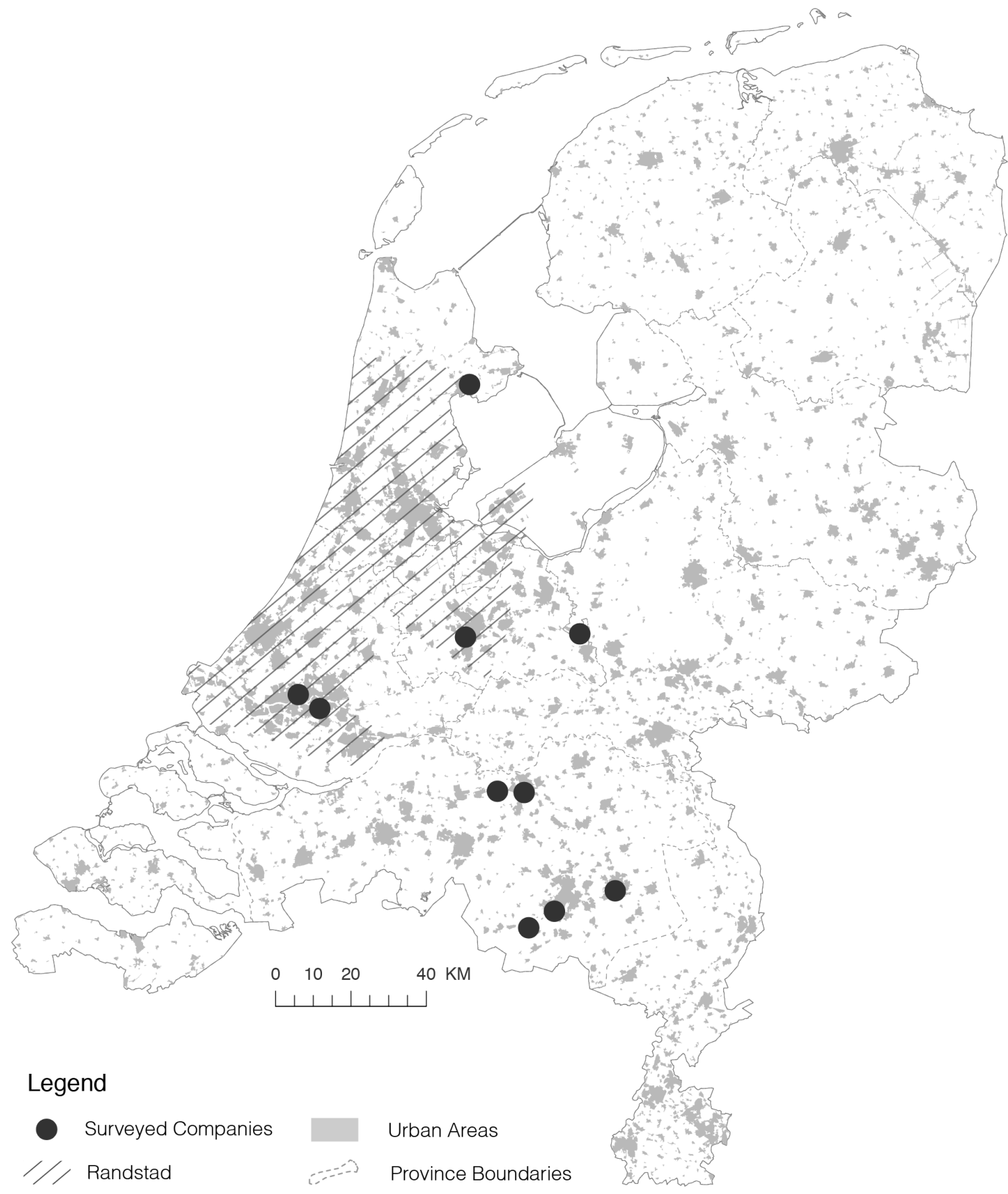




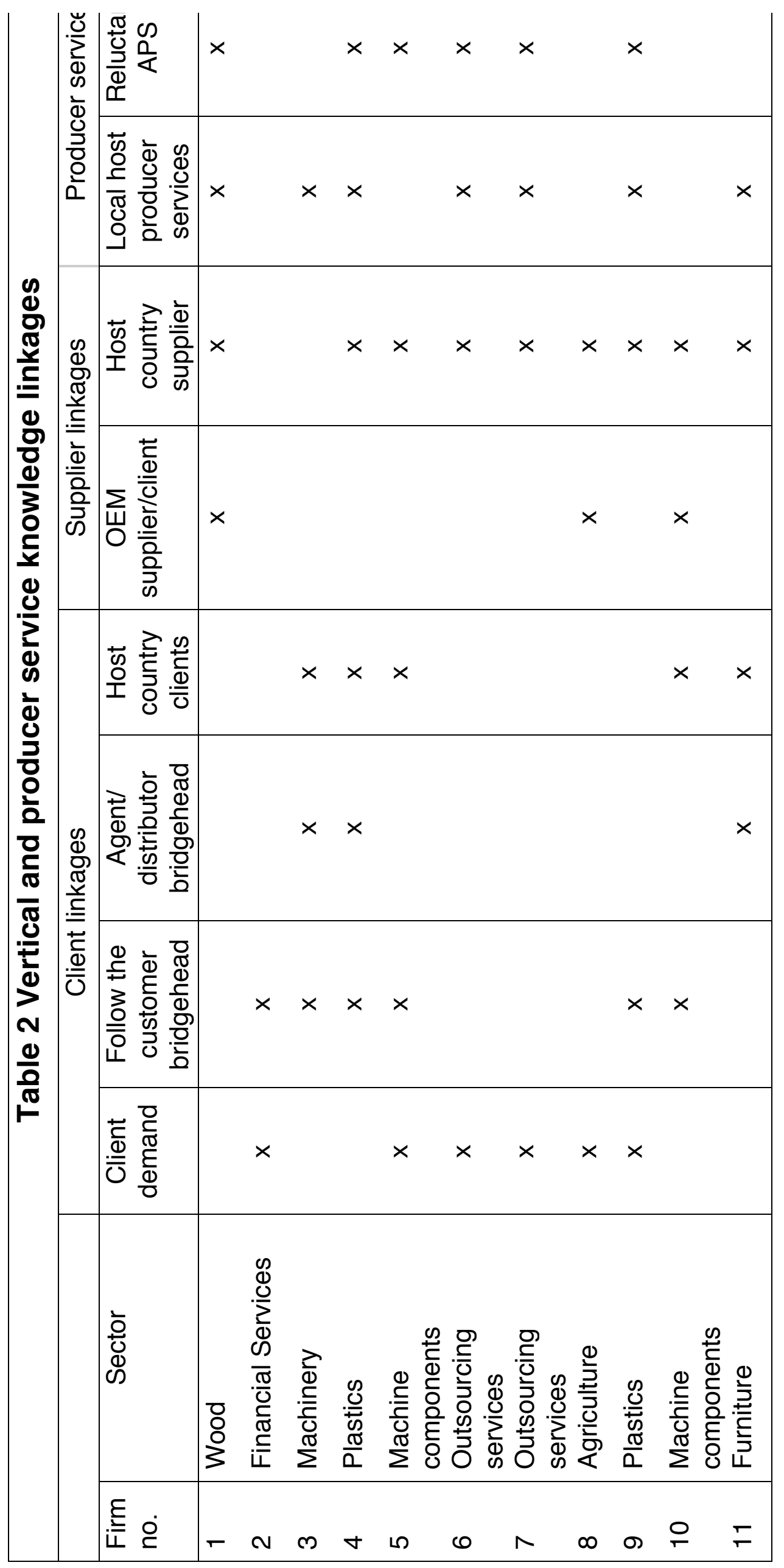


Table 3 Horizontal knowledge linkages

\begin{tabular}{|l|l|c|c|c}
\hline Firm no. & \multicolumn{1}{|c|}{ Sector } & $\begin{array}{c}\text { Mimicry } \\
\text { effects }\end{array}$ & $\begin{array}{c}\text { Competitor } \\
\text { knowledge sharing }\end{array}$ & $\begin{array}{c}\text { Peer' knowledge } \\
\text { sharing }\end{array}$ \\
\hline 1 & Wood & $\mathrm{x}$ & $\mathrm{x}$ & \\
2 & Financial Services & $\mathrm{x}$ & & $\mathrm{x}$ \\
3 & Machinery & $\mathrm{x}$ & $\mathrm{x}$ & \\
4 & Plastics & & $\mathrm{x}$ \\
5 & Machine components & & & \\
6 & Outsourcing services & & $\mathrm{x}$ & \\
7 & Outsourcing services & & $\mathrm{x}$ & \\
8 & Agriculture & & $\mathrm{x}$ & $\mathrm{x}$ \\
9 & Plastics & & & \\
10 & Machine components & & & \\
11 & Furniture & &
\end{tabular}

